\title{
Kinerja Jangka Panjang Kolom Hasil Perbaikan Dengan Bahan Tambah Bonding Adhesive Agent
}

\author{
Cindy Deniswara; Richardo Pelipus B.R.; \\ Rr.M.I. Retno Susilorini dan Budi Santosa \\ cindydeniswara94@gmail.com dan richardomesang123@gmail.com \\ Program Studi Teknik Sipil, Fakultas Teknik \\ Universitas Katolik Soegijapranata, Semarang
}

\begin{abstract}
The research was conducted to investigate the performance of old repaired columns in Sriwulan Village (Sayung) and Pucang Gading. The performance of 3 columns was investigated by non destructive test and destructive test at age of repaired columns at 12, 13, and 14 months. Non destructive test conducted by Hammer Test while destructive test conducted by Core Drill Test. The results of research has shown that from Hammer Test, highest compressive strength at age 14 months was 45,65 MPa. For Core Drill Test results, the highest compressive strength 73,62 MPa found in Pucang Gading at column 1 at zone A by age 14 months while the lowest at same site and column at zone C 14,22 MPa.
\end{abstract}

Keyword : destructive test, compressive strength, core drill test, hammer test

\begin{abstract}
ABSTRAK
Penelitian ini dilakukan untuk mengetahui kinerja kolom jangka panjang di Desa Sriwulan (Sayung) dan Pucang Gading dimana kolom telah mengalami perbaikan sebelumnya. Kinerja kolom jangka panjang diketahui dengan Uji Tidak Merusak (non destructive test) dan Uji Merusak (destructive test) pada 3 buah kolom dengan umur perbaikan 12,13, dan 14 bulan. Uji tidak merusak dilakukan dengan Percobaan Palu dan Uji merusak dilakukan dengan Uji Bor inti. Hasil penelitian dengan Percobaan Palu menunjukkan bahwa diperoleh hasil 45,65 MPa. Untuk hasil penelitian dengan Uji Bor inti diperoleh hasil 48,13 MPa. Perbandingan hasil penelitian antara Percobaan Palu dan Uji Bor inti menunjukkan nilai kuat tekan tertinggi pada zona A (Atas) Pucang Gading 73,62 MPa dan terendah di Sayung zona C (Bawah) sebesar $14,22 \mathrm{MPa}$.
\end{abstract}

Kata kunci : uji merusak, kuat tekan, uji bor inti, percobaan palu 


\section{PENDAHULUAN}

Pada jaman sekarang penggunaan beton sudah sangat banyak untuk dipilih dan digunakan sebagai konstruksi bangunan seperti gedung, rumah, jalan, jembatan dan lain sebagainya.Pembangunan konstruksi bangunan pun banyak di daerah sekitaran laut.

Dalam hal pembuatan beton dan perawatannya (curing) tentu saja ada yang membedakan perlakuan terhadap beton yang akan digunakan di daerah sekitaran laut dan yang tidak di daerah sekitaran air laut. Terkadang tidak hanya air laut namun ketika permukaan air laut mulai naik air rob akan masuk ke daratan. Kualitas beton dapat ditentukan berdasarkan keawetan beton (durability of concrete) tersebut, keawetan dapat ditentukan dari ketahanan beton terhadap kondisi lingkungan sekitar. Kondisi lingkungan sekitar pun bermacammacam bisa dikarenakan hujan, air rob, air laut, panas terik matahari, angin dan lain sebagainya.

Desa Sriwulan menjadi salah satu desa yang berlokasi di daerah sekitaran air laut yang banyak menggunakan beton sebagai bahan utama pembangunan infrastruktur seperti rumah tinggal dan bangunan lainnya, dikarenakan mudah dalam pengerjaannya serta tahan lama (durable).Akan tetapi beton juga memiliki kelemahan diantaranya sulit untuk kedap air secara sempurna, sehingga selalu dapat dimasuki air dan air yang membawa kandungan garam dapat merusak beton.

Air rob di Desa Sriwulan disebabkan oleh penurunan permukaan tanah dan perubahan pemanfaatan ruang di pesisir pantai yang semula adalah hutan bakau berubah menjadi area pertambakan dan pemukiman warga. Beberapa rumah tinggal di Desa Sriwulan mengalami kerusakan karena seringnya terendam ai rob.
Berdasarkan hal diatas, maka akan dilakukannya Uji Tidak Merusak (non destructive) yaitu Hammer Test dan Uji Merusak (destructive) yaitu Core Drill untuk mengetahui perbandingan saat beton kolom mengalami 10 kali pukulan hammer test pada umur 12, 13, dan 14 bulan serta pengeboran pada 3 (tiga) titik beton kolom pada umur 14 bulan.

Penelitian ini merupakan bagian dari penelitian payung "Strategi Adaptasi Masyarakat Pesisir Semarang dan Demak untuk Mitigasi Pengurangan Resiko Bencana Banjir dan Rob Akibat Perubahan Iklim” (Susilorini, et.al, 2017) yang memperoleh pendanaan dari INSINAS RPI (2017-2019) Kemristekdikti ;Kontrak No.35/INS/PPK/E/E4/2017.

Penelitian ini diharapkan dapat bermanfaat terhadap perbaikan karakteristik beton (kuat tekan permukaannya) di daerah yang rawan mengalami rob, sehingga dengan adanya penelitian ini berpengaruh untuk meningkatkan mutu dan durabilitas beton. Selain itu juga dapat menambah pengetahuan tentang penggunaan bonding adhesive agent yang adalah bahan peningkat daya lekat semen pada aplikasi umum seperti beton, plesteran,maupun acian khususnya untuk kolom di daerah rawan mengalami rob.

\section{METODE PENELITIAN}

\section{METODE PENGUJIAN}

Secara eksperimental dengan Uji Merusak dan UJi Tidak Merusak .

\section{PROSEDUR PELAKSANAAN}

Adapun langkah-langkah yang dilakukan dalam penelitian ini adalah sebagai berikut :

a. Pengumpulan tinjauan pustaka sebagai sumber ilmiah yang meliputi dan mencangkup penelitian untuk pengujian hammer dan core drill . 
b. Pengambilan data hasil nilai kuat tekan dengan hammer test pada kajian penelitian terdahulu umur 7,14, dan 28 hari sebagai perbandingan nilai kuat tekan kolom di umur 12,13, dan 14 bulan.

c. Survey lokasi kolom terkena oleh air rob (Desa Sriwulan, Kecamatan Sayung, Kabupaten Demak) dan lokasi kolom tidak terkena oleh air rob (Perumnas Jl. Pucang Elok Raya ,Pucang Gading, Kota Semarang).

d. Pengukuran ketinggian air rob yang menggenangi kolom menggunakan papan ukur dari kayu

e. Pengujian kuat tekan kolom beton dengan Hammer Test pada umur 12, 13, dan 14 bulan di Sayung dan Pucang Gading

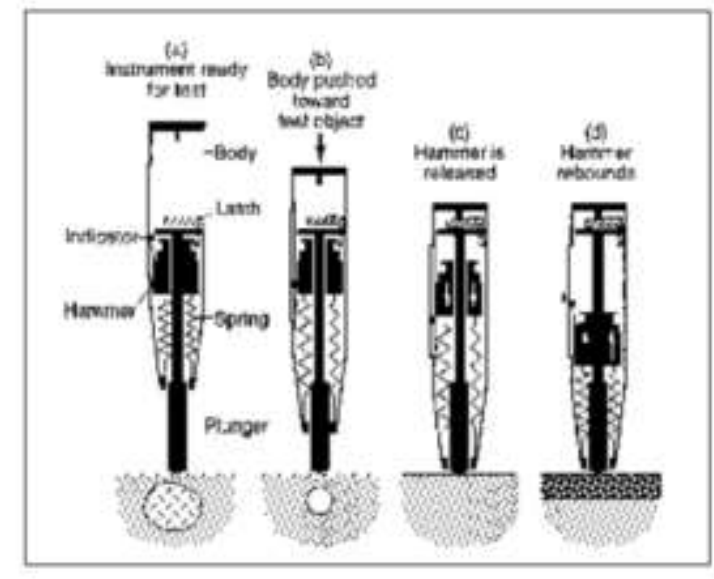

Gambar 1. Ilustrasi Skematik Cara Kerja Rebound Hammer( ACI 228. 1R-95)

(Sumber : ACI 228.1R-95)

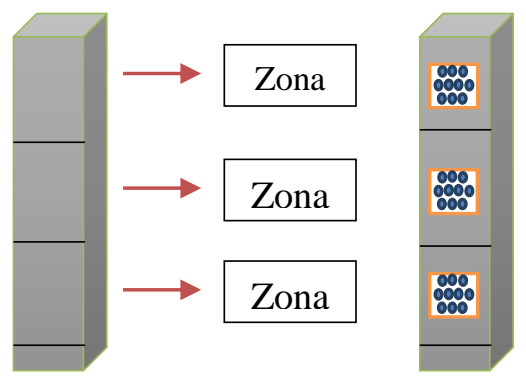

Gambar 2. Perencanaan Hammer Test

Salah Satu Sisi Depan Kolom

Dengan 10 kali Tembakan
Hammer Test akan dilakukan pada kolom hasil perbaikan dengan 4 (empat) sisi dari 3 (tiga) zona kolom yaitu $\mathrm{A}, \mathrm{B}$, dan $\mathrm{C}$ dengan jumlah pukulan tiap sisi sebanyak 10 (sepuluh) kali.

f. Pengujian kuat tekan kolom beton dengan menggunakan Core Drill pada umur 14 bulan di Sayung dan Pucang Gading.

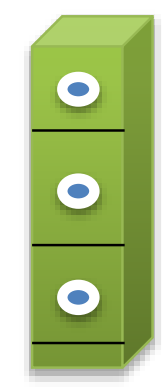

\section{Gambar 3, Perencanaan Core Drill Dengan Tiga Zona PemboranPada Satu Sisi Kolom}

Core Drill akan dilakukan pada kolom hasil perbaikan dengan 3 (tiga )titik mewakili 3 (tiga ) zona kolom yaitu A, $\mathrm{B}$, dan $\mathrm{C}$.

g. Perekapan data hasil pengujian penelitian terdahulu dengan Hammer Test dan Core Drill pada waktu 12, 13, dan 14 bulan

h. Pembuatan grafik perbandingan Hammer Test umur 7,14, dan 28 hari (Kajian Penelitian Terdahulu) dengan Hammer Test umur 12, 13, dan 14 bulan (perencanaan) dengan perhitungan standar deviasi.

i. Pembuatan diagram batang hasil perbandingan uji Core Drill pada umur 14 bulan di lokasi Desa Sriwulan dengan Pucang Gading

j. Kesimpulan hasil data kuat tekan terbesar dan terkecil pegujian Hammer Test dan Core Drill 


\section{LANDASAN TEORITIS}

Kuat Tekan

Kuat tekan merupakan sifat beton yang paling utama dan akan berhubungan degan sifat - sifat lainya, kuat tekan tinggi akan sebanding dengan sifat lainnya (Tjokrodimulyo, 2007). Pada pengerjaan Tugas Akhir ini kuat tekan beton dan mortar diuji berdasarkan ASTM C3 dengan rumus sebagai berikut:

$\sigma=\frac{P}{A}$

Keterangan:

$\boldsymbol{\sigma}$ : Tegangan normal yaitu kuat tekan beton $\left(\mathrm{N} / \mathrm{mm}^{2}\right)=\mathrm{Mpa}$

P : Beban tekan $(\mathrm{N})$

A : Luas daerah yang tertekan $\left(\mathrm{mm}^{2}\right)$

\section{DIAGRAM ALIR}

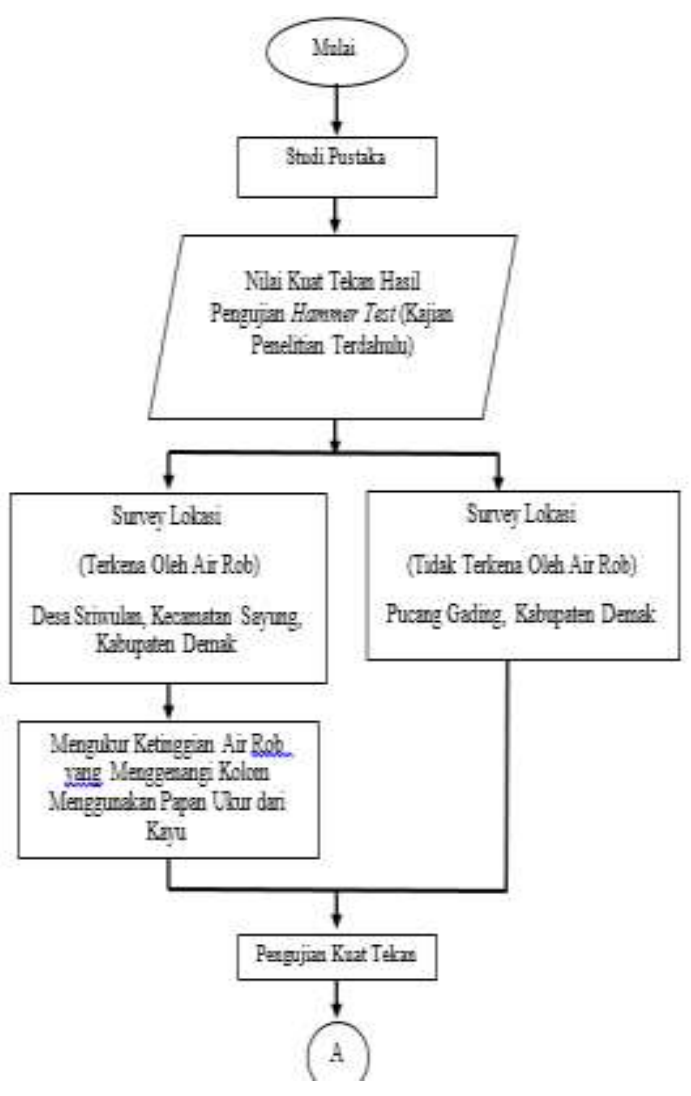

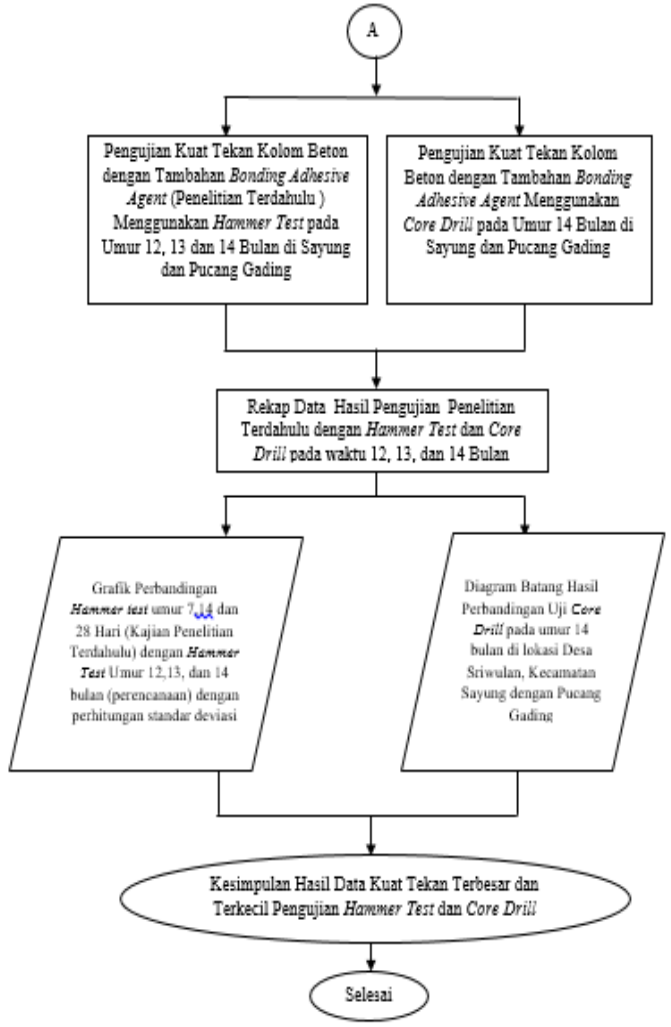

HASIL DAN PEMBAHASAN

Kuat Tekan Hammer Test

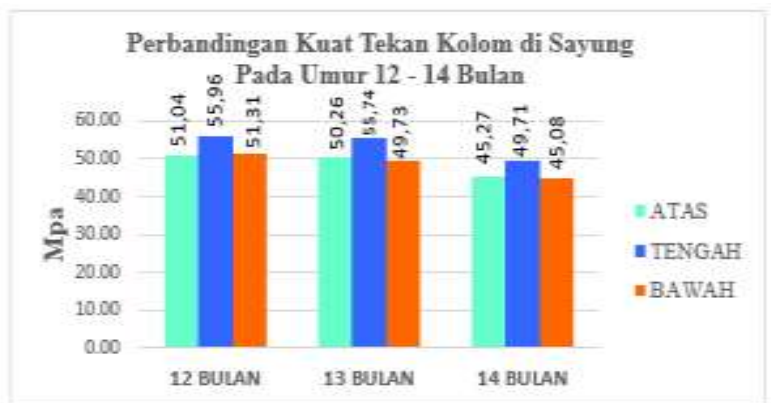

Diagram 1. Perbandingan Rerata Kuat Tekan (MPa) Pengujian Hammer Test Kolom Hasil Perbaikan dengan Bahan Tambah Bonding Adhesive Agent Pada Umur 12, 13, dan 14 Bulan di Sayung.

Pada umur 12 bulan diperoleh kuat tekan tertinggi pada Zona Tengah sebesar 55,96 MPa dan kuat tekan terendah pada Zona Atas dengan hasil sebesar 51,04 MPa. Pada umur 13 bulan didapatkan kuat tekan tertinggi pada Zona Tengah 55,74 MPa dan kuat tekan terendah pada Zona Bawah sebesar 49,73 MPa. Pada umur 14 bulan 
hasil kuat tekan tertinggi diperoleh dengan Zona Tengah sebesar 49,71 MPa dan kuat tekan terendah diperoleh pada Zona Bawah sebesar 45,08 MPa. Dari hasil kuat tekan diatas dapat diberi kesimpulan bahwa kuat tekan pengujian pada umur 12, 13, dan 14 bulan mengalami penurunan di setiap zona kolomnya dan tiap bulannya.

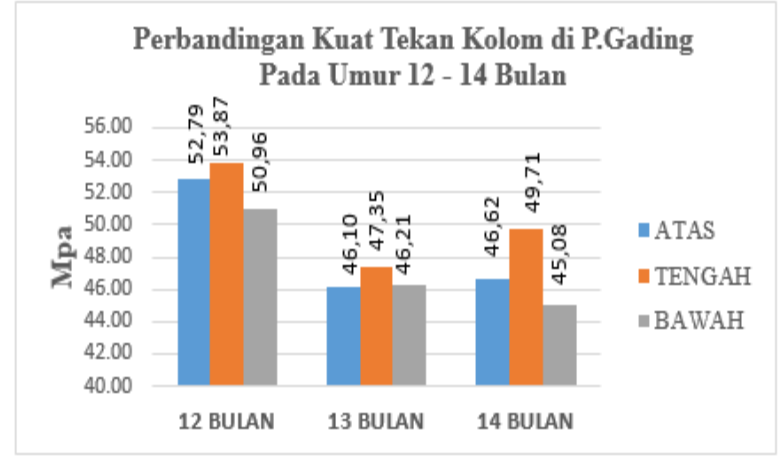

Diagram 2. Perbandingan Rerata Kuat Tekan (MPa) Pengujian Hammer Test Kolom Hasil Perbaikan dengan Bahan Tambah Bonding Adhesive Agent Pada Umur 12, 13, dan 14 Bulan di Pucang Gading

Pada umur kolom 12 bulan hasil kuat tekan tertinggi didapatkan pada Zona Tengah dengan 53,87 $\mathrm{MPa}$ sedangkan hasil kuat tekan terendah diperoleh Zona Bawah sebesar 50,96 MPa. Pada umur 13 bulan hasil kuat tekan kolom tertinggi diperoleh Zona Tengah sebesar 47,35 MPa dan kuat tekan terendah didapatkan Zona Atas sebesar 46,10 MPa. Pada umur 14 bulan didapatkan hasil kuat tekan kolom tertinggi pada Zona Tengah sebesar 49,71 MPa dan hasil kuat tekan terendah pada Zona Bawah sebesar 45,08 MPa. Dari hasil kuat tekan dapat disimpulkan bahwa pada Zona Atas hasil kuat tekan di 12 bulan ke 13 bulan mengalami penurunan yang kemudian meningkat 0,52 MPa di 14 bulan. Pada Zona Tengah mengalami hal yang sama pada Zona Atas yaitu penurunan yang kemudian mengalami peningkatan sebesar 2,36 $\mathrm{MPa}$ di 14 bulan. Hanya pada Zona Bawah yang terus mengalami penurunan pada hasil kuat tekan di setiap bulannya.

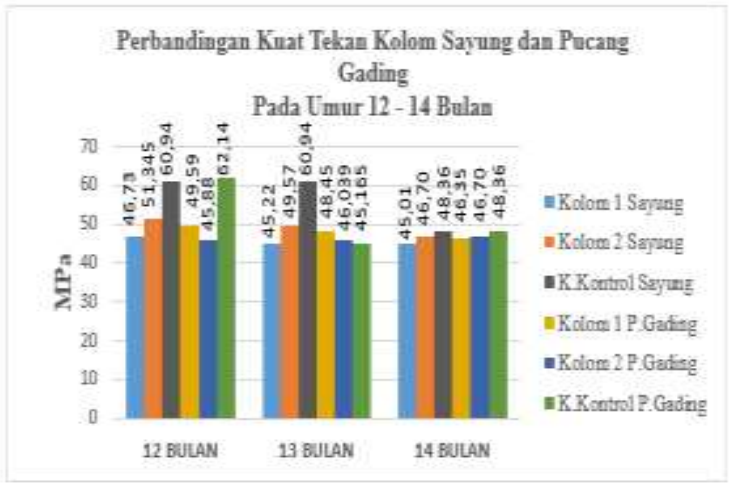

Diagram 3. Perbandingan Rerata Kuat Tekan (MPa) Pengujian Hammer Test Kolom Hasil Perbaikan di Sayung dan Rerata Kuat Tekan Pengujian Hammer Test Kolom di Pucang Gading Pada Umur 12, 13, dan 14 Bulan

Pada umur 12 bulan hasil kuat tekan tertinggi didapatkan pada kolom kontrol di Pucang Gading sebesar 62,14 MPa dan hasil kuat tekan terendah didapatkan pada kolom 2 hasil perbaikan dengan lem beton sebesar 45,88 MPa. Pada umur 13 bulan hasil kuat tekan tertinggi diperoleh pada kolom kontrol di Sayung sebesar 60,94 $\mathrm{MPa}$ sedangkan hasil kuat tekan terendah diperoleh pada kolom kontrol di Pucang Gading sebesar 45,16 MPa. Pada umur 14 bulan hasil kuat tekan tertinggi diperoleh kolom kontrol di Sayung dan Pucang Gading sebesar 48,36 MPa sedangkan hasil kuat tekan terendah diperoleh kolom 1 hasil perbaikan dengan bahan tambah SikaCim berbasis bonding adhesive agent sebesar 45,01 MPa. Dapat disimpulkan dari grafik diatas bahwakuat tekan tertinggi justru diperoleh pada kolom kontrolyang merupakan sebagai kolom pembanding dengan kolom hasil perbaikan menggunakan bahan tambah berupa lem beton maupun SikaCim yang berbasis bonding adhesive agent. 


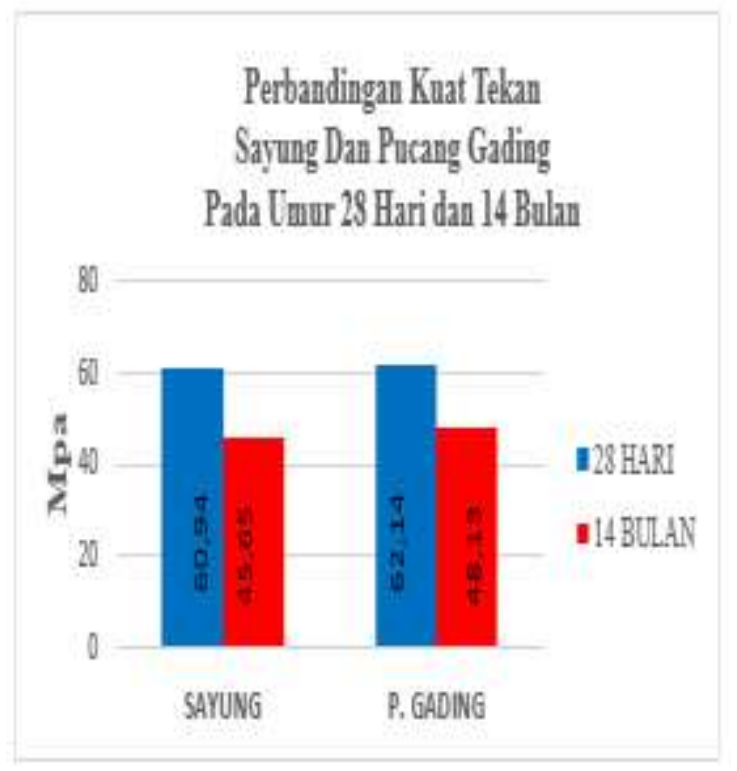

Tekan (MPa) Pengujian Hammer Test Kolom Hasil Perbaikan di Sayung dan Rerata Kuat Tekan Pengujian Hammer Test Kolom di Pucang Gading Pada Umur 28 Hari dan 14 Bulan

Perbandingan rerata kuat tekan (MPa) pengujian hammer test kolom hasil perbaikan di Sayung dan rerata kuat tekan pengujian hammer test kolom di Pucang Gading pada umur 28 hari dan 14 bulan. Pada lokasi Sayung rerata terakhir pada pengujian sebelumnya didapatkan hasil kuat tekan sebesar 60,94 MPa dan kemudian mendapatkan hasil kuat tekan di 14 bulan sebesar 45,65 MPa. Pada lokasi Pucang Gading pada pengujian sebelumnya diperoleh hasil kuat tekan 62,14 MPa dan kemudian mendapatkan hasil kuat tekan 14 bulan sebesar 48,13 MPa. Kesimpulan dapat diambil sesuai gambar diatas yaitu hasil kuat tekan mengalami penurunan setelah 14 bulan pada lokasi Sayung maupun di Pucang Gading.

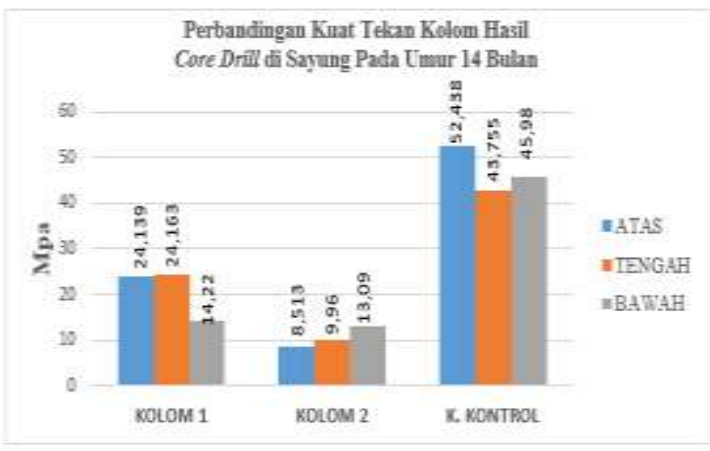

Diagram 5. Perbandingan Rerata Kuat Tekan (MPa) Pengujian Core Drill Kolom Hasil Perbaikan di Sayung Setiap Zona Pada Umur 14 Bulan

Perbandingan kuat tekan kolom hasil core drill di Sayung pada umur 14 bulan didapatkan hasil yang terbesar diperoleh pada kolom kontrol pada Zona Atas sebesar 52,49 MPa. Sedangkan hasil terendah diperoleh pada kolom kontrol dengan Zona Tengah sebesar 43,76 MPa. Pada kolom 1 dan kolom 2 mengalami hasil yang kecil dibandingkan dengan hasil kuat tekan yang dimiliki kolom kontrol disebabkan karena riwayat kolom yang merupakan kolom praktis yang diperbaiki menggunakan sistem chipping dan grouting yang kemudian proses pengecorannya tidak mengalami kerataan yang sempurna dan kepadatannya yang kurang sempurna yang dapat terlihat pada Gambar 4.8 sebelumnya lapisan yang terlihat berbeda antara bagian atas ,tengah, dan bawahnya.

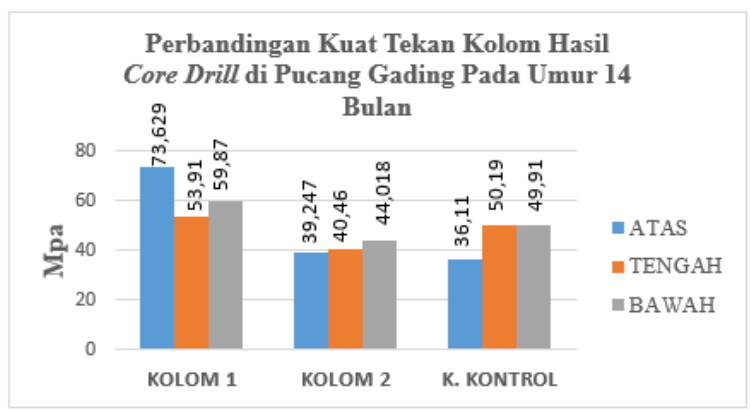

Diagram 6. Perbandingan Rerata Kuat Tekan (MPa) Pengujian Core Drill Kolom Hasil Perbaikan di Pucang Gading Setiap Zona Pada Umur 14 Bulan 
Perbandingan kuat tekan kolom hasil core drill di Pucang Gading pada umur 14 bulan didapatkan hasil yang terbesar diperoleh pada kolom kontrol pada Zona Atas sebesar 73,63 MPa. Sedangkan hasil terendah diperoleh pada kolom kontrol dengan Zona Atas sebesar 36,11 MPa. Pada kolom 2 mengalami hasil yang kecil dibandingkan dengan hasil kuat tekan yang dimiliki kolom 1 dan kolom kontrol, ini disebabkan karena bahan tambahan pada kolom 1 bekerja dengan baik dan dan cukup kuat untuk bertahan di kondisi di sekitarnya (daerah Pucang Gading).

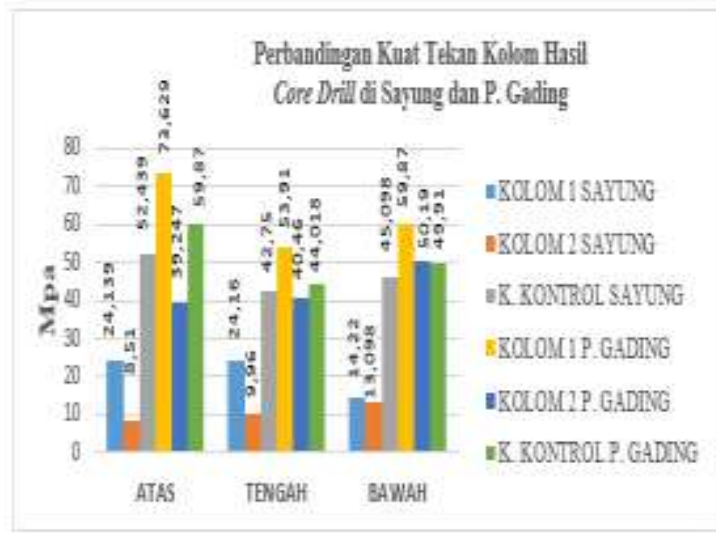

Diagram7. Perbandingan Rerata Kuat Tekan (MPa) Pengujian Core Drill Kolom Hasil Perbaikan di Sayung dan Pucang Gading Setiap Zona Pada Umur 14 Bulan

Berdasarkan data diatas yang merupakan hasil pengujian core drill kemudian dilanjutkan dengan pengujian kuat tekan pada benda uji yang diambil dari daerah Sayung dan Pucang Gading menunjukkan bahwa rata-rata benda uji yang berasal dari Pucang Gading memiliki kuat tekan yang lebih baik dari pada benda uji yang diambil dari daerah Sayung. Beberapa faktor yang meyebabakan adalah kondisi lingkungan pada daerah Sayung yang sering terjadi rob menyebabkan beton mudah rusak. Penyebab lain adalah pada saat kolom di pucang Sayung di perbaiki, beton lama dan beton baru yang ditambahkan bercampur sehingga saat ditekan beton mudah pecah dan angka kuat tekannya menjadi kecil.

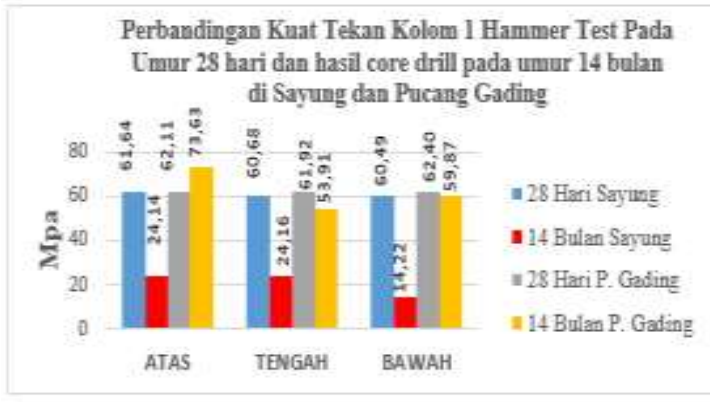

Diagram 8. Perbandingan Rerata Kuat Tekan (MPa) Kolom 2 Pada Umur 28 Hari dan Hasil Core Drill Pada Umur 14 Bulan di Sayung dan Pucang Gading Tiap Zona

Perbandingan rerata kuat tekan (MPa) kolom 2 hammer test pada umur 28 hari dan pada umur 14 bulan dengan pengujian core drill di dua lokasi berbeda yaitu Sayung dan Pucang Gading didapatkan hasil kuat tekan tertinggi pada kolom 1 Zona Atas umur 14 bulan Pucang Gading. Sedangkan hasil kuat tekan terendah terdapat pada kolom 1 Zona Bawah umur 14 bulan sebesar 14,22 MPa.

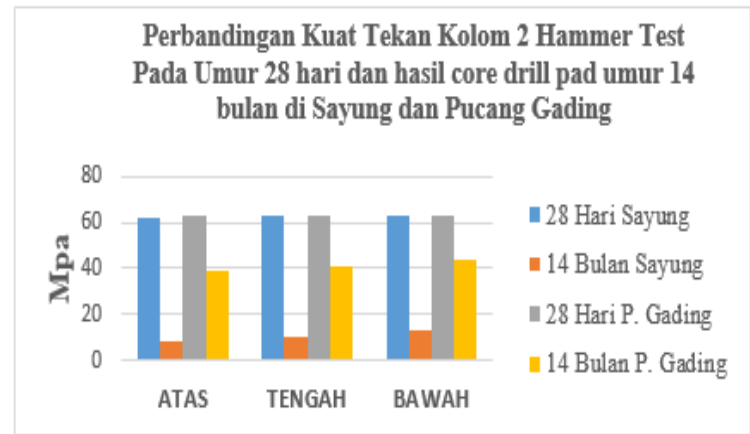

Diagram 9. Perbandingan Rerata Kuat Tekan (MPa) Kolom 2 Pada Umur 28 Hari dan Hasil Core Drill Pada Umur 14 Bulan di Sayung dan Pucang Gading Tiap Zona

Perbandingan hasil kuat tekan kolom 2 hammer test pada umur 28 hari dan kuat tekan kolom core drill umur 14 bulan didapatkan hasil tertinggi pada kolom 2 di lokasi Sayung pada Zona Bawah dengan umur benda uji 28 hari. Sedangkan pada hasil terendah didapatkan pad kolom 2 lokasi Sayung dengan Zona Atas pada umr 14 bulan. 


\section{KESIMPULAN}

Berdasarkan hasil pengamatan dan pengujian yang dilakukan pada kolom hasil perbaiakan dengan bahan tambahan bonding adhesive agent pada daerah Sayung dan daerah Pucang Gading dapat diuraikan beberapa kesimpulan sebagai berikut :

a. Kolom hasil perbaikan dengan bahan tambahan bonding adhesive agent pada daerah Sayung cenderung mengalami penurunan kekuatan, disebabkan oleh kondisi lingkungan yang ekstrem dikarenakan kolom terendam dengan airrob yang mengakibatkan kekuatan dari kolom beton selama 28 hari sampai dengan 14bulan cenderung mengalami penurunan kekuatannya.

b. Kolom hasil perbaikan dengan bahan tambahan bonding adhesive agent pada daerah Pucang Gading ada yang mengalami penurunan kekuatan ada juga yang kekuatannya stabil, dikarenakan di lokasi Pucang Gading dalam keadaan kering tanpa terendam air rob.

\section{SARAN}

Setelah melakukan pengujian terhadap kolom yang diperbaiki dengan bahan tambahan bonding adhesive agent, maka saran yang dapat diberikan yaitu setelah mendapatkan hasil dari pengujian ini terlihat adanya penurunan kekuatan pada kolom beton yang menggunakan bahan tambah berbasis bonding adhesive agent dengan umur 12 bulan, maka pada rumah tinggal yang berlokasi disekitar daerah rob akan menjadi bahan pertimbangan dalam pembangunannya dengan memberi standar kekuatan kolom ditujukan agar rumah tinggaldikawasan air rob akan tetap kokoh.

\section{DAFTAR PUSTAKA}

ASTM C.42-94.Standard Test Method for Obtaining and Testing Drilled Cores and Sawed Beams of Concrete :

Annual Books of ASTM Standards.

ASTM C 494/C 494M-05a. 2006. Standard Specification for Chemical Admixtures for Concrete. USA : Annual Books of ASTM Standards.

ASTM C150-02a. Standar Spesifikasi untuk Semen Portland.Annual Books of ASTM Standards.

Bakti, L. M. 2010. Kajian Sebaran Potensi Rob Kota Semarang dan Usulan Penanggulangannya, Tesis Program Magister Teknik Sipil, Fakultas Teknik, Universitas Diponegoro Semarang.

Hunggurami, Elia., Utomo, Sudiyo., dan Wadu, Amy. 2014. Pengaruh Masa Perawatan (Curing) Menggunakan Air Rob Terhadap Kuat Tekan Dan Absorpsi Beton, Jurusan Teknik Sipil, FST Undana, Kupang.

Lubis, Mawardi. 2003. Pengujian Struktur Beton Dengan Metode Hammer Test dan Metode Uji Pembebanan (Load Test). Jurusan Teknik sipil, Fakultas Teknik, Universitas Sumatera Utara.

Mulyono, Tri 2004.Teknologi Beton, Jakarta. Penerbit Andi.

Neville, AM. (1999). Properties of Concrete Fourth and Final Edition. Person Education Limited, England.

PBI 1971 Peraturan Beton Bertulang Indonesia. Direktorat Penyelidikan Masalah Bangunan, Bandung.

SNI 15-2049-1994. Portland Semen, Jakarta.

Sudarmoko, 1996.Diagram Perancangan

Kolom Beton Bertulang, Jurusan

Teknik Sipil, Fakultas Teknik, Universitas Gadjah Mada, Yogyakarta. 
Susilorini, Rr. M. I. Retno., Hardjasaputra, Harianto., dan Tudjono, Sri. 2014. Inovasi Beton Bajik untuk Beton Berkelanjutan, Laporan Akhir, Hibah Kompetensi Tahun Pertama, Ditlitabmas, Ditjen Dikti.

Susilorini, M. I. Retno, dan Suwarno, Djoko. 2009. Mengenal dan Memahami Beton, Buku Ajar. Penerbit Laboratorium Bahan Bangunan, Jurusan Teknik Sipil, Unika Soegijapranata Semarang.

Susilorini, Rr.M.I. Retno, Suwarno, Djoko, dan Santosa, Budi.2017. Strategi Adaptasi Masyarakat Pesisir Semarang dan Demak untuk Mitigasi Pengurangan Resiko Bencana Banjir dan Rob Akibat Perubahan Iklim. Laporan Akhir INSINAS Riset Pratama Individu Direktorat Penguatan Teknologi Industri, Direktorat Jenderal Riset dan Pengembangan, Kemenristekdikti.

Tjokrodimuljo, K. 1995. Teknologi Beton. Buku Ajar, Jurusan Teknik Sipil, Fakultas Teknik, Universitas Gajah Mada. Yogyakarta.

Tjokrodimuljo, K. 1996. Teknologi Beton. Buku Ajar, Jurusan Teknik Sipil, Fakultas Teknik, Universitas Gajah Mada. Yogyakarta.

Tjokrodimuljo, Kardiyono 2007.Teknologi Beton. Biro Penerbit Jurusan Teknik Sipil Fakultas Teknik UGM, Sleman, Daerah Istimewa Yogyakarta.

Wikana, I dan Robloly, L. 2008.Tinjauan Kuat Lentur Panel Menggunakan Bahan Tambah Ampas Tebu dan Sikacim Bonding adhesive, Program Studi Teknik Sipil, Fakultas Teknik, UKRIM Yogyakarta.

Sugiyono. Prof.,Dr. 2011. Metode Penelitian Kuantitatif, Kualitatif, dan $R \& D$, Alfabeta, Bandung.
Purwanto dan Suharyadi. 2009. Statistika untuk Ekonomi dan Keuangan Modern Edisi 2, Salemba Empat, Jakarta.

Supardi., Dr. 2013. Aplikasi Statistika Dalam Penelitian, Change Publication, Jakarta. 